\title{
Reflections on the Face of Japan: A Multivariate Craniofacial and Odontometric Perspective
}

C.L. BRACE, M.L. BRACE, AND W.R. LEONARD

Museum of Anthropology, University of Michigan,

Ann Arbor, Michigan 48109

\author{
KEY WORDS Craniofacial form, Dentition, Ainu, Asia, Oceania, \\ Jömon, Yayoi
}

\begin{abstract}
Craniofacial variables for modern and prehistoric Japanese were subjected to multivariate analysis to test the relationships of the people of Japan with mainland Asian and Oceanic samples. The modern Japanese are tied to Koreans, Chinese, Southeast Asians, and the Yayoi rice agriculturalists who entered Japan in 300 B.C. Together they make up a Mainland-Asia cluster of related populations. The prehistoric Jōmon foragers, the original inhabitants of the Japanese archipelago, are the direct ancestors of the modern Ainu, who made a recognizable contribution to the warrior class-the Samurai-of feudal Japan. Together, they are associated with Polynesians and Micronesians in a Jömon-Pacific cluster of related populations. Jomon-to-Ainu tooth size reduction proceeded at the same rate as that observable in the post-Pleistocene elsewhere in the Old World.
\end{abstract}

According to legend, the Japanese are of divine origin (cf. the Nihongi, Aston, 1896 [1956], translator), with the rulers claiming the Sun goddess, Amaterasu, as a progenitor, and others claiming descent from her younger brother, Susano-o (Lu, 1974). When myths and folk tales are subjected to critical analysis, many interpreters have detected hints of a southerly origin for many things Japanese, although whether that "south" was the southwestern island of Kyūshū (Sansom, 1958) or something considerably farther afield (Vivien de Saint-Martin, 1872; Morse, 1878; Sternberg, 1929; Koganei, 1937; Ohno, 1970) remains a matter for debate. Although our own attempt to deal with the problem of Japanese origins and relations concentrates on the information to be gained from an assessment of craniofacial form, we cannot deny that a full anthropological appraisal has to take a series of nonbiological aspects into account. A summary of the views generated by the work done in those relevant aspects is presented below.

\section{THE LINGUISTIC PERSPECTIVE}

Linguists also have debated about the nature of the origins of the Japanese language.
Many have noted the phonological, morphological, and semantic features that tie Japanese and Korean to Uralic and Altaic (Ohno, 1970; Miller, 1971, 1974, 1980; Chew, 1978). In the opinion of one authority (Miller, 1986: p. 110), this shows that Japanese can trace its lineage back to a "relatively undifferentiated proto-Altaic linguistic unity," presumably in the region of the Heilongjiang (Amur River) drainage area on the Sino-Russian border. Others have identified what they believe to be an Austronesian ("Malayo-Polynesian") element in Japanese (Vivien de Saint-Martin, 1872; Sternberg 1929; Ohno, 1970; Befu, 1971; Murayama, 1972, 1976), but they differ on whether there was an Austronesian language spoken in Jōmon Japan, which was subsequently obliterated to a large extent by the intrusive Altaic languages (Ohno, 1970; Befu, 1971), or whether the original languages were Altaic and the Austronesian elements were introduced by small groups of intruders who subsequently became absorbed (Miller, 1980; Aikens and Higuchi, 1982). Although interest in the possibility of an Austronesian "substrate" in

Received November 9, 1987; accepted May 26, 1988. 
Japanese has now waned to the extent that it is not even mentioned in the most recent treatment of the linguistic evidence for Japanese origins (Miller, 1986), we think that, in the light of the conclusions we reach in this paper, it is a matter that should be systematically reexamined.

\section{THE ARCHAEOLOGICAL PERSPECTIVE}

Since the crucial events that contributed to the populating of Japan all occurred before the dawn of recorded history, there is more than a small element of extrapolation and conjecture in the attempts of students of folklore and linguistics to clarify matters. There are a couple of other realms of investigation that can provide more direct evidence concerning those prehistoric events. One of these involves the work of the archaeologists who have studied the actual cultural remains that have survived from prehistoric Japan. Even though many conflicting interpretations remain in contention, archaeology has provided solid data and holds out the promise that a firm framework for understanding the events of Japanese prehistory is close to being achieved.

In broad terms, two main periods can be identified. The first of these, the Jōmon, extends from more than 12,000 years ago until 300 B.C. (Ikawa-Smith, 1980, 1982; Pearson, 1986). Although the Jommon people are generally regarded as "affluent hunter-gatherers" engaged in the "intensive collection of a wide variety of wild foods" (Akazawa, 1982a: p. 57), it would appear that they also may have practiced some form of slash-and-burn agriculture more than 6,000 years ago (Tsukada, 1986) and may have adopted irrigated rice in the northern Kyūshū area before the advent of the next period (Akazawa, 1982b).

The Jōmon period was succeeded by the Yayoi period, which has traditionally been associated with the introduction to Japan of intensive rice agriculture, table-turned pottery, weaving, and the use of metals (Ohno, 1970; Befu, 1971; Bowles, 1977; Ikawa-Smith, 1980; Aikens and Higuchi, 1982). The Yayoi lasted from 300 B.C. to A.D. 300 (Akazawa, $1982 \mathrm{~b}$ ), although an excellent case has been made that the succeeding Kofun (tomb) period (A.D. 300-600) (Ikawa-Smith, 1980) is simply a continuation of the Yayoi right up to the point where the written record begins with the Nara state in the seventh century (Barnes, 1986; H Kanaseki, 1986). While these broad outlines are generally agreed upon, there are also major areas of disagreement. Specifically, what was the relation between the Jōmon and the succeeding Yayoi? Was it a case of a new population with a different subsistence technology invading from the mainland (Befu, 1971; Kagawa, 1973), or was it a case of the adoption of new techniques by the in situ Jömon people, who simply continued and expanded in the lands where they had been shaped (Aoki and Omoto, 1980; Akazawa, 1982a,b, 1986; H Kanaseki, 1986)? From an appraisal of the archaeological evidence currently available, this question cannot be resolved, but from an appraisal of the surviving tangible remains from prehistoric Japan-namely, the skeletons of the people themselves-we are going to suggest a choice indicated by the results of our analysis.

\section{THE AINU QUESTION}

Obviously we have to use a consideration of the modern inhabitants of Japan as our main point of reference in assessing the genesis of modern Japanese facial form. Consequently our analysis will utilize samples of modern Japanese from the northeastern, the central, and the southwestern parts of the archipelago. Complicating the matter is the fact that not all of the native inhabitants of the Japanese realm are traditionally regarded as "Japanese." Specifically, the inhabitants of the northern island of Hokkaido, the Ainu, have long been regarded as "racially" different from the rest of the people of Japan (Busk, 1867; Koganei, 1894; von Baelz, 1901, 1911; Chamberlain, 1912; S Watanabe, 1938, 1981). Currently there are very few unmixed Ainu left due to interbreeding with the incoming Japanese during the last hundred years (Omoto 1970, 1972). But Hokkaidō did not become a part of the territory of Japan until the Meiji restoration in 1868 (H Watanabe, 1986), at which time the Ainu constituted the recognized population of the island. Although they have traditionally been looked down upon as "primitive," and stigmatized as "mere" hunter-gatherers, they evidently engaged in the same kind of ingenious and intensive exploitation of the available natural resources that had characterized the preceding Jōmon throughout Japan (H Watanabe, 1986). Furthermore, they and their predecessors planted and harvested a variety of millets and perhaps other crops as well, so they should more correctly be viewed 
as having pursued a mixed subsistence economy rather than as having been hunter-gatherers in the strict sense (Crawford and Yoshizaki, 1987).

According to legendary, historical, and linguistic testimony regarding the Japanese, however, "All their traditions point to their coming from the south, and equally sure are we that when they landed they found a race of hairy men to contest their occupation" (Morse, 1878). Subsequently, somewhere between the fifth and the eighth century when the semilegendary Japanese emperor, Jimmu Tennō, led his forces from the southwestern island of Kyūshū to conquer the Yamato plain (the Yamato district now includes modern Nara and Osaka in central Japan), he was apparently opposed by "a population of Aino race" (Aston, 1896 [1956]: p. 109, footnote 1). As late as the twelfth century, Japan's 'Wild East" was the Kanto plain, the location of the modern city of Tökyo, where the indigenous Ainu continued to block the northeastward spread of the power of the Japanese state right up to "feudal" times (Storry, 1978).

Further, the use of place names in the northeastern end of the main island of Honshū (Ohno, 1970) "shows that eastern Japan used languages related to Ainu in late Jōmon and Yayoi times" (Chew, 1978: p. 200). In fact, "the names of very many places all over Japan, which are purely Ainu"-and this includes southern Japan as wellprompted the assertion that "enough have been brought forward to show clearly strong grounds for the belief that the Ainu once inhabited the whole of the Japanese empire" (Batchelor, 1892: pp. 284, 292, 295).

In the past, it was also observed that there were distinct traces of Ainu features to be seen toward the northern end of Honshū (and also in the southern corner of Kyūshū and in the Ryukyus) (von Baelz, 1911). As Chamberlain (1912: p. 181) remarked, "The 'Ainu type' among the Japanese is most marked in the north, where these pre-Japanese aborigines continued longest." Dermatoglyphic (Mitsuhashi, 1967) and serological (Harvey et al., 1978; Mourant, 1980) data from the modern Japanese also sustain such a view.

Who the Ainu are and where they came from has engaged the imagination of observ. ers of Japan for over a century. In contrast to the other peoples of Asia, they are famous for their display of hirsutism: male beards and body hair being its particular manifestation.
From the time of La Pérouse at the end of the eighteenth century on up to the present, the opinion has frequently been offered that they represent a far-eastern outlier of European or "Caucasoid" form (Busk [reflecting the opinion of Huxleyl, 1867; Bickmore, 1868; von Baelz, 1901, 1911; Koganei, 1927; Hooton, 1946). Other suggestions concerning their source range from the Tower of Babel (Kaempfer, 1906) and nonserious reflections about a "lost tribe of Israel" (Batchelor, 1892), to considering them as a northward extension of Polynesian (Vivien de Saint-Martin, 1872; Sternberg, 1929) or Southeast Asian groups (Levin, 1961; Turner and Hanihara, 1977; Turner, 1986), to looking at them as just another form of "Mongoloid" (Hanihara, 1970, 1977; Omoto, 1970; Omoto and Harada, 1975), and finally to regarding them as a northern representation of Australian aboriginal form (Hooton, 1946; Birdsell, 1951, 1967-noting that both considered "Australoid" to be a "primitive" kind of "Caucasoid" form). The last of these claims has been definitively refuted on craniometric (Yamaguchi, 1967), serological (Omoto and Misawa, 1976), and odontometric (Hanihara, 1976, 1977) grounds. These same studies also show the unlikelihood of a European connection, but there are also dental and cranial studies that equally call into question the suggestion that they are "just another Mongoloid" population (Turner, 1976, 1979, 1983; Howells, 1986; Brace et al., in press). The Polynesian matter cannot be so easily dismissed, as has previously been noted (Yamaguchi, 1967; Brace and Nagai, 1982; Brace et al., in press), and as we shall develop at greater length later in this paper.

\section{SAMPLES USED}

Here we record the groups we have used and the addresses of the collections in which they are located. In each instance, we include the number of individuals with enough complete dimensions to be used in our multivariate treatment of craniofacial form. Odontometrics were collected from the same samples, but because we could get tooth measurements from many individuals who were otherwise incomplete, the numbers involved tend to be considerably larger than those associated with a relatively complete set of craniofacial data. The exception is the Mongols, where the sample was so small that we could not get a measurement for each 
category of tooth, so no TS figure could be calculated.

The following list includes the sample identity and number of the specimens used to assess the relations of craniofacial form in Asia and the Pacific. Japanese: 271 specimens; Kyūshū (Southwest), 27 specimens, Department of Anatomy, Nagasaki University School of Medicine, Nagasaki; Tōkyo (East Central), 113 specimens, University Museum, University of Tōkyo, Hongo, Bunkyo-ku, Tōkyo; Chiba (East Central), 74 specimens, Department of Anatomy II, Sapporo Medical College, Sapporo; Tōhoku (Northeast), 57 specimens, Department of Anatomy, School of Medicine, Töhoku University, Sendai; Medieval Samurai: 17 specimens (Kamakura, A.D. 1333), University Museum, University of Tōkyo; Ainu: 55 specimens, University Museum, University of Tōkyo and Department of Anatomy II, Sapporo Medical College; Kofun: 4 specimens, Department of Anatomy, Medical School, Kyūshū University and Department of Anatomy, School of Medicine, Tōhoku University; Yayoi: 21 specimens, Fukuoka and Doigahama, Department of Anatomy, Medical School, Kyūshū University, Fukuoka; Jōmon: 12 specimens (Early Jömon 1, Middle Jōmon 2, Late Jōmon 6 specimens), Department of Anatomy II, Sapporo Medical College and Laboratory of Physical Anthropology, Faculty of Science, Kyōto University, Kyōto; Nagasaki "Yayoi", 3 specimens, Department of Anatomy, Nagasaki University School of Medicine; Chinese: 398 specimens; East Coast, 174 specimens, Biology Section, Department of Biology, Fudan University, Shanghai, People's Republic of China; North China, 40 specimens, University Museum, University of Tōkyo; Western China (Sichuan), 69 specimens, Department of Anatomy, Chengdu College of Traditional Chinese Medicine, Chengdu, Sichuan, People's Republic of China; Southwest China (Hunnan), 64 specimens, Institute of Vertebrate Paleontology and Paleoanthropology, People's Republic of China; South China, 70 specimens, Department of Anatomy, Guangxi Medical College, Nanning, Guangxi Zhuang Autonomous Region, People's Republic of China; Southeast China (Hong Kong), 45 specimens, Department of Oral Anatomy, Prince Philip Dental Hospital, Hong Kong; North Chinese Neolithic: 18 specimens, Institute of Vertebrate Paleontology and Paleoanthropology, Beijing; Koreans: 17 specimens, University
Museum, University of Tōkyo; Mongols: 11 specimens, Department of Anthropology, American Museum of Natural History, New York, NY; Micronesians: 55 specimens, (Guam 36) Department of Anthropology, Bernice P. Bishop Museum, Honolulu, HI. (Yap 5, Palau 5, Mortlock 4, Carolines 1, Chamorro 1, Jaluit 1, Naru 1, Tari-Tari 1) von Luschan Collection, American Museum of Natural History, New York, NY; Philippinos: 21 specimens (Visayas), Museum of Anthropology, University of Michigan, Ann Arbor, MI; Polynesians: 131 specimens, (Easter Island 11, New Zealand 25, Marquesas 26 specimens) American Museum of Natural History, New York, NY; Hawaiian: 69, Bernice P. Bishop Museum, Honolulu, HI; Thai: 65 specimens, Department of Anatomy, Siriraj Hospital, Mahidol University, Bangkok, Thailand; Thai Neolithic: 2 specimens, Sood Sangvichien Museum of Prehistory, Siriraj Hospital, Bangkok, Thailand; Vietnamese: 5 specimens, Musée de l'Homme, Paris, France.

\section{DATA COLLECTED}

In previous studies where broad sweeps of time and long-term changes in selective forces were the objects of concern, a simple focus on dental metrics was sufficient to demonstrate major trends in the course of hominid evolution (Brace, 1979a,b; Brace et al., 1987). Where this approach was essayed to demonstrate the selective-force differences in the backgrounds of a series of contemporary modern populations-for example, in Australia and Oceania (Brace, 1980; Brace and Hinton, 1981)-the question could be legitimately raised as to whether the differences observed were really indicators of the differential operation of selective forces or whether they might indicate that the groups under consideration had come from widely separate areas in the recent past where genetic drift or some other such mechanism had produced different effects.

When the dental metrics of both moderns and their predecessors in the recent past were collected in both Japan and China (Brace and Nagai, 1982; Brace et al., 1984), an attempt to check for the possibility of immigration vs. continuity through time was made by assessing aspects of craniofacial form. In the case of Japan, the obvious differences between the Jomon and the modern Japanese were noted at the same time that it was realized that the contrast in form between the Japanese and the Ainu involved exactly the same 
TABLE 1. Craniofacial measurements

\begin{tabular}{cl}
\hline Variable No. & \multicolumn{1}{c}{ Description } \\
\hline 1 & Nasal height (Martin No. 55) \\
2 & Nasal bone height (Martin No. 56 [2]) \\
3 & Nasion prosthion (Martin No. 44 [1]) \\
4 & Nasion basion (Martin No. 5) \\
5 & Basion prosthion (Martin No. 40) \\
6 & Superior nasal bone width (Martin No. 57 [2]) \\
7 & Minimum nasal bone width \\
8 & Inferior nasal bone width (Martin No. 57 [3]) \\
9 & Nasal breadth (Martin No. 54) \\
10 & Simotic subtense (Howells) \\
11 & Height of rhinion over measurement number 8 \\
12 & IOW subtense at nasion (Woo and Morant) \\
13 & Mow subtense at rhinion (Woo and Morant) \\
14 & Bizygomatic width (Martin No. 45) \\
15 & Glabella opisthocranion (Martin No. 1) \\
16 & Maximum cranial breadth (Martin No. 8) \\
17 & Basion bregma (Martin No. 17) \\
\hline
\end{tabular}

traits. These points were first made by Koganei $(1927,1937)$, whose discussion remains a model of accurate assessment. The argument can always be made, however, that this kind of morphological assessment is subjective at bottom and therefore unscientific. Fortunately, the quantitative treatments of nonmetric aspects of the dentition (Turner, $1976,1979,1983,1985 \mathrm{a}, \mathrm{b}, 1986$, in press) and skull (Dodo, 1986; Ossenberg, 1986) have reached exactly the same conclusions.

\section{Craniofacial metrics}

With this in mind, we attempted to quantify those aspects of craniofacial morphology which had been the basis of the earlier subjective assessment of group relationships and differences, noting that Yamaguchi had done this successfully on a more limited set of samples $(1967,1982)$ and that Howells has repeatedly demonstrated that multivariate statistics elegantly confirm the conclusions reached by Koganei well over half a century ago (Howells, 1966, 1986). Evidently this approach works for much the same reason that massive DNA comparisons work (cf. Sibley and Ahlquist, 1984, 1986); i.e., if enough individual pieces of information are accumulated, the degree of similarity in pattern will reflect the degree of genetic relationship in spite of the particular effects of differences in selective force history. This is apparently why different workers using different sets of measurements on similar population samples come to the same general conclusions in regard to population relationships and distinc- tions (Howells, 1966, 1973, 1986, in press; Pietrusewsky, 1971, 1979, 1981, 1983, 1984, in press; Brace et al., in press).

The list of measurements we applied to the samples mentioned above is to be found in Table 1. Well over half of the eighteen measurements included deal with aspects of nasal elevation and elongation since it was our preliminary observation that it was in these traits that the most obvious distinctions between the Jomon and the Japanese and between the north and the south Chinese were to be found. As it happened, essentially the same roster was also successful in assessing the relationships of the peoples of Oceania, Australia, and continental Asia (Brace et al., in press).

\section{Odontometrics}

Mesial-distal and buccal-lingual measurements were made for all of the available teeth-maxillary and mandibular, right and left-for all of the individuals available in the samples used for the present study. The measurement techniques have been previously discussed in detail (Brace, 1979b, 1980). Since the right and left antimeres are phenotypic expressions of the same underlying genotype, the best expression of the latter is an average of the two. Individual dimensions for each tooth class, then, were calculated from the means of the antimere measurements. In order to produce a sample figure for a given tooth class dimension, the midsex mean was used-that is, the sum of the mean 
TABLE 2. Summary tooth size measurements (TS) in $\mathrm{mm}^{2}$

\begin{tabular}{|c|c|c|c|}
\hline Sample & $\mathrm{TS}$ & Mean $N$ & Range of $\mathrm{N}$ \\
\hline Micronesia, Guam & 1,311 & 70 & $(38-88)$ \\
\hline China, North & 1,261 & 26 & $(12-35)$ \\
\hline Sendai & 1,250 & 23 & $(12-37)$ \\
\hline Kofun & 1,245 & 29 & $(12-71)$ \\
\hline Japan, Chiba & 1,240 & 57 & $(32-68)$ \\
\hline China, Neolithic & 1,236 & 152 & $(57-278)$ \\
\hline Yayoi & 1,232 & 9 & $(3-18)$ \\
\hline Korea & 1,229 & 22 & $(14-44)$ \\
\hline Japan, Edo & 1,222 & 42 & $(7-89)$ \\
\hline Thai, Neolithic & 1,222 & 46 & $(30-61)$ \\
\hline Thai & 1,222 & 27 & $(23-31)$ \\
\hline China, Sichuan & 1,208 & 37 & $(2-90)$ \\
\hline China, Yunnan & 1,206 & 65 & $(4-168)$ \\
\hline Jōmon, Early & 1,205 & 5 & $(3-8)$ \\
\hline Kamakura & 1,197 & 43 & $(30-50)$ \\
\hline China, Shanghai & 1,197 & 107 & $(25-234)$ \\
\hline Japan, Nagasaki & 1,188 & 30 & $(17-38)$ \\
\hline China, Guangxi & 1,186 & 46 & $(27-63)$ \\
\hline Polynesia & 1,172 & 138 & $(104-170)$ \\
\hline Vietnam & 1,169 & 9 & $(2-21)$ \\
\hline China, Hong Kong & 1,154 & 37 & $(29-45)$ \\
\hline Jōmon, Middle & 1,152 & 18 & $(7-30)$ \\
\hline Jömon, Late & 1,151 & 47 & $(18-73)$ \\
\hline Ainu & 1,141 & 83 & $(53-106)$ \\
\hline Nagasaki, "Yayoi" & 1,093 & 6 & $(5-8)$ \\
\hline
\end{tabular}

male and the mean female dimensions divided by two (Brace et al., 1987). In this fashion, the mean mesial-distal and mean buccallingual dimensions of each of the sixteen tooth classes were calculated for each sample. The result yielded thirty-two figures for each group considered.

In order to simplify this, cross-sectional areas were produced by taking the product of the mesial-distal and buccal-lingual dimensions for each tooth class. As was the case for the individual mesial-distal and buccal-lingual dimensions, the sample figure was considered to be the midsex mean of the crosssectional area for each tooth class.

This still leaves sixteen data points per sample, and while this provides a very effective means of comparing two or three groups at a time, there can be real confusion when the number of groups being compared rises to ten or more. Under the latter circumstances, a crude but effective measure is provided by the use of the summary tooth-size figure, TS. This is simply the sum of the mean crosssectional areas of all the tooth categories in a single sample (Brace, 1978, 1979b, 1980). As with the means for individual measurement and cross-sectional areas, the mean TS of a sample is a mid-sex mean.

Table 2 displays the TS figures for the samples used in this study arranged in order of magnitude. Since each TS figure is based on a summary of mean individual tooth crosssectional areas and since each of these has a different $\mathrm{N}$, there is no way to calculate a variance for the TS figures presented here. As was noted in a previous study which included the analysis of complete individuals where such variance figures could be calculated, "a summary tooth-size difference of $50 \mathrm{~mm}^{2}$ between groups compared is probably meaningful, and a difference of $100 \mathrm{~mm}^{2}$ or more almost certainly has some basic biological meaning" (Brace, 1980; Brace and Ryan, 1980).

\section{ANALYSIS}

In our use of the craniofacial measurements listed in Table 1, we have followed the procedures for the treatment of variables described by Howells (1986). This is an attempt to minimize the effects of major size differences when comparing diverse populations. The first step in this procedure is to convert individual unweighted measurements into sex-specific Z-scores where each Z-score represents the number of standard deviation units by which the value in question departs from the grand mean for each separate dimension of all the samples used in a given analysis. This can be represented as: 


$$
\mathrm{Z}_{\mathrm{ij}}=\frac{\left(\mathrm{X}_{\mathrm{ij}}-\overline{\mathrm{X}}_{\mathrm{i}}\right)}{\sigma_{\mathrm{i}}}
$$

where: $\mathrm{i}=$ number of the measurement (e.g. 1 ...18); $\mathrm{j}=$ number of the individual; $\mathrm{X}_{\mathrm{ij}}=$ value of measurement "i" for individual "e"; $\mathrm{X}_{\mathrm{i}}=$ overall sex specific average value for measurement "i"; and $\sigma_{i}=$ overall sex specific standard deviation for measurement " $i$ ".

The use of Z-scores by themselves does not eliminate the problem of size. In order to deal with the matter of relative proportion or "shape" of the craniofacial features with which we are concerned, some kind of proportional transformation would be desirable. Recently, Howells (1986) has proposed the use of the C-score statistic to accomplish this purpose. C-scores are similar to ratios in that they both are measures of relative size. The advantage of a $\mathrm{C}$-score over a simple ratio is that the C-score reflects relative size of a given feature in comparison to the size of all the other traits used, while a ratio can only reflect relative size in comparison to a single referent. C-scores are calculated as the difference between the Z-score of a single measurement for a given individual and the mean $\mathrm{Z}$ score of that individual for all the measurements used in the analysis.

The mean Z-score for a single individual is calculated in the following fashion:

$$
\bar{Z}_{j}=\frac{\sum Z_{i j}}{N}
$$

where: $\overline{\mathrm{Z}}_{j}=$ the average Z-score for all the variables for individual " $\mathrm{j}$ "; and $N=$ the number of variables used (e.g., 18 if all are represented).

Given this, then, the $\mathrm{C}$-score is:

$$
\mathrm{C}_{\mathrm{ij}}=\mathrm{Z}_{\mathrm{ij}}-\overline{\mathrm{Z}}_{\mathrm{j}}
$$

The C-scores were then used as the basis for constructing dendrograms representing the relationships of the various groups sampled. Actually, we made a great many trial dendrograms. Initially we used the untransformed data. Subsequently we repeated these trials using Z-scores, and finally we settled on the use of C-scores as defined above. We also made trials without the use of fre- quently missing variables in an attempt to maximize our sample sizes. In the final analysis, however, we used an approach that maximized discrimination even though it had the effect of reducing our sample sizes. This seemed to produce the most reliable results where reliability was determined by the consistency with which samples known to be related were put into the same cluster after the addition or subtraction of other samples in the course of constructing our various trial dendrograms.

The dendrograms we have produced are hierarchical trees based on calculations of Euclidean distance, a procedure that produces results similar to those achieved by Ossenberg (1986) and by Dodo and Ishida (1987) using Mean Measures of Distance of nonmetric cranial variables. The logic is discussed in Sneath and Sokal (1973), and the computation procedure is the one specified in Fox and Guire (1976). This is a multivariate procedure which requires values for all of the variables used in the analysis. In our case, since the calculation of $\mathrm{C}$-scores requires that a Z-score value be present for each variable for each individual included, this means that we could only use individuals on whom a complete set of measurements could be made. And because of the problem of artificially maximizing common variance that occurs when regression procedures are used to estimate missing data, we avoided the use of any kind of interpolation to fill in missing variables. This is why the $\mathrm{N}$ for many of our samples is as small as it is, especially for the often-fragmentary prehistoric groups.

Before constructing each dendrogram, the program evaluates the importance of each variable by a stepwise linear multiple discriminant procedure. The variable with the greatest power of discrimination is used first. Subsequent variables are then added in order of importance until it is determined that the contribution to reliability has a $P$ value of $\geqslant .05$. Since this procedure is done automatically each time a dendrogram is constructed, there is always the possibility that dendrograms with different samples will have been built with the use of slightly differing sets of variables. Indeed, this is the case for the three dendrograms we have presented here-namely, Figures 1-3. For example, six of the first seven variables that contributed to the dendrogram illustrated in Figure 1 , numbers $2,12,14,18,8$, and 7 , were related to the nose. The first five vari- 


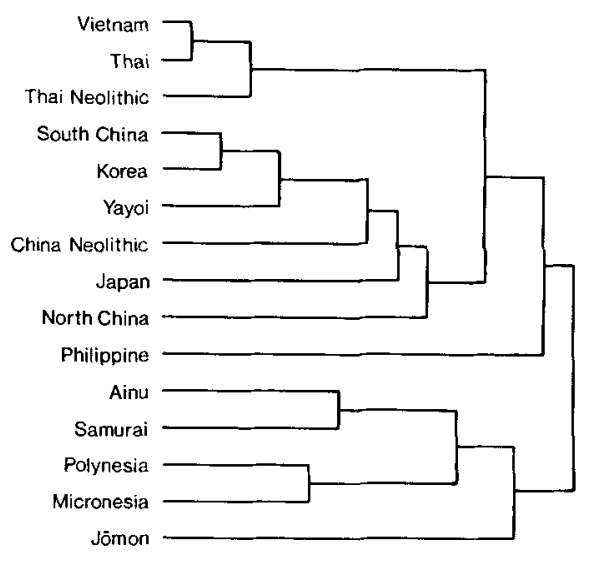

Fig. 1. A Euclidean distance dendrogram showing the relationships between modern and prehistoric groups from the Japanese archipelago. A numerical expression of these relationships can be seen in Table 6 .

ables that contributed to the construction of the dendrogram in Figure 2 were also measures of nasal elongation and projection. And the first eight variables that contribute to the picture shown in Figure 3 are also related to the nose. The lists of variables in the order that they were used in the construction of Figures 1-3, plus their F-statistics and significance values, are shown in Tables 3-5.

After constructing our dendrograms, we used the same samples and the same variables to construct a matrix of Mahalanobis distance $\left(D^{2}\right)$ figures (Fox and Guire, 1976). These are presented in Tables 6-8. In essence these provide a numerical version of the relationships visually evident in Figures 1-3.

It is clear from the data in Figure 1 and an appraisal of the form shown in Figures 4 and 5 that the various levels of Jomon and the modern Ainu are basically the same kind of thing, so we have some reason to consider that they represent the continuity of a single lineage through time. For that reason, we feel justified in treating the evident odontometric reduction through time as a picture of real evolutionary change. Figure 6 shows the regression line produced when tooth size data are entered for the appropriate time levels. Early Jōmon is assigned an antiquity of 7,000 B.P., Middle Jōmon an age of 4,000 B.P., Late Jōmon an age of 2,000 B.P., and we gave the Ainu burials a date of A.D. 1000. The Jōmonto-Ainu regression line has a slope of -0.0090

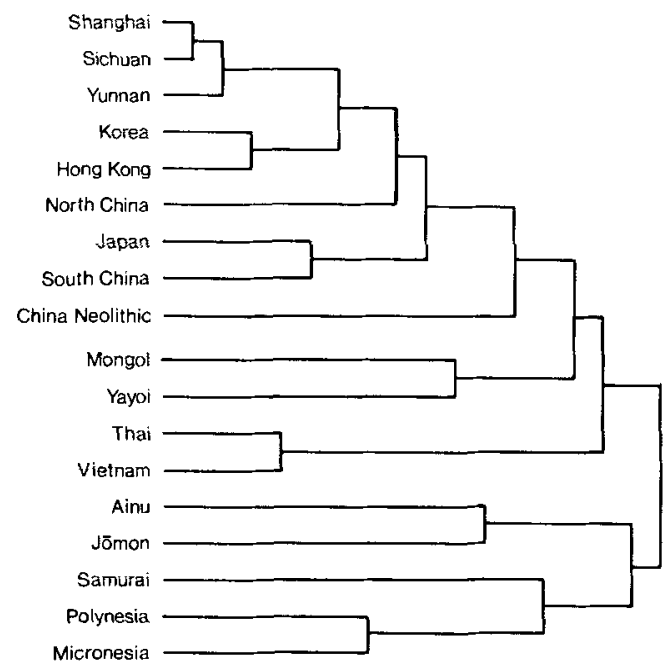

Fig. 2. A Euclidean distance dendrogram showing the relationships between prehistoric and combined modern Japanese groups, combined Polynesians, combined Micronesians, and a series of mainland Asian groups. A numerical expression of these relationships can be seen in Table 7 .

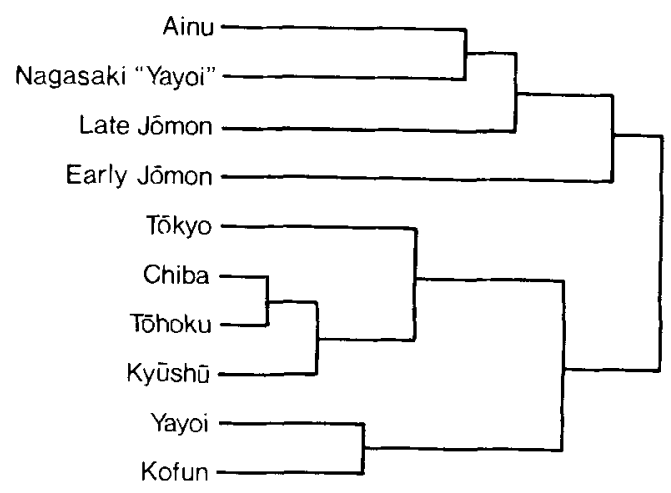

Fig. 3. A Euclidean distance dendrogram showing the relationships between the various distinct Japanese and Oceanic samples with a spectrum of mainland Asian samples simplified by combining the coastal, southern, and western Chinese into a single "South" Chinese group. A numerical expression of these relationships can be seen in Table 8 .

$\mathrm{mm}^{2} / \mathrm{yr}$ and an $r$ value of $.631(P=.09)$. This makes a reasonable comparison with the $\mathrm{Me}$ solithic-to-Neolithic-to-modern slopes in Europe $(-0.0123, r=.888, P=.0003)$, China 
TABLE 3. Sequence of entry of variables used to produce Figure 1

\begin{tabular}{rlrr}
\hline \multicolumn{1}{c}{ Variable } & & F-statistic & Significance \\
\hline No. & \multicolumn{1}{c}{ Name } & 26.180 & .0000 \\
2 & Nasal bone height & 8.922 & .0000 \\
12 & IOW subtense at nasion & 6.150 & .0000 \\
14 & Bizygomatic width & 5.767 & .000 \\
18 & Basion rhinion & 3.428 & .005 \\
8 & Inferior nasal bone width & 2.961 & .002 \\
7 & Minimum nasal bone width & 2.365 & .013 \\
\hline
\end{tabular}

TABLE 4. Sequence of entry of variables used to produce Figure 2

\begin{tabular}{rlrr}
\hline \multicolumn{1}{r}{ No. } & \multicolumn{1}{c}{ Name } & & Sariable \\
18 & & F-statistic & .0000 \\
2 & Basion rhinion & 36.170 & .0000 \\
1 & Nasal bone height & 12.784 & .0000 \\
12 & Nasal height & 12.211 & .0000 \\
9 & IOW subtense at nasion & 9.259 & .0000 \\
16 & Inferior nasal bone width & 7.896 & .0000 \\
17 & Maximum cranial breadth & 7.158 & .0000 \\
14 & Basion bregma & 7.046 & .0000 \\
3 & Bizygomatic breadth & 6.687 & .0000 \\
8 & Nasion prosthion & 6.286 & .0000 \\
13 & Inferior nasal bone width & 5.448 & .0000 \\
15 & MOW subtense at rhinion & 5.563 & .0000 \\
5 & Glabella opisthocranion & 4.725 & .0000 \\
4 & Basion prosthion & 3.412 & .0006 \\
10 & Nasion basion & 2.530 & .0036 \\
6 & Simotic subtense & 2.186 & .0011 \\
\hline
\end{tabular}

TABLE 5. Sequence of entry of variable used to produce Figure 3

\begin{tabular}{rlcc}
\multicolumn{1}{r}{ Variable } & & F-statistic \\
\hline No. & \multicolumn{1}{c}{ Name } & 44.627 & Significance \\
\hline 18 & Basion rhinion & 16.329 & .0000 \\
2 & Nasal bone height & 13.337 & .0000 \\
1 & Nasal height & 12.352 & .0000 \\
3 & Nasion prosthion & 10.403 & .0000 \\
12 & IOW subtense at nasion & 9.067 & .0000 \\
13 & MOW subtense at rhinion & 7.882 & .0000 \\
8 & Inferior nasal bone width & 7.778 & .0000 \\
9 & Nasal breadth & 7.089 & .0000 \\
15 & Glabella opisthocranion & 3.935 & .0000 \\
17 & Basion bregma & 3.794 & .0000 \\
5 & Basion prosthion & 4.012 & .0000 \\
14 & Bizygomatic width & 4.362 & .0000 \\
16 & Maximum cranial breadth & 3.221 & .0000 \\
10 & Simotic subtense & 3.135 & .0001 \\
6 & Superior nasal bone width & 2.431 & .0001 \\
4 & Nasion basion & 1.952 & .0023 \\
7 & Minimum nasal bone width & & .0186 \\
\hline
\end{tabular}

$(-0.0129, r=.922, P=.003)$, Southeast Asia are often only marginally more recent than $(-0.017, r=.947, P<.001)$, and the Middle those called Middle Jōmon and, as can be East $(-0.0165, r=.892, P=.04)$ (Brace et al., seen from Table 2, the TS of both is effecin press). Those groups called Late Jomon tively the same. The one group that was ar- 

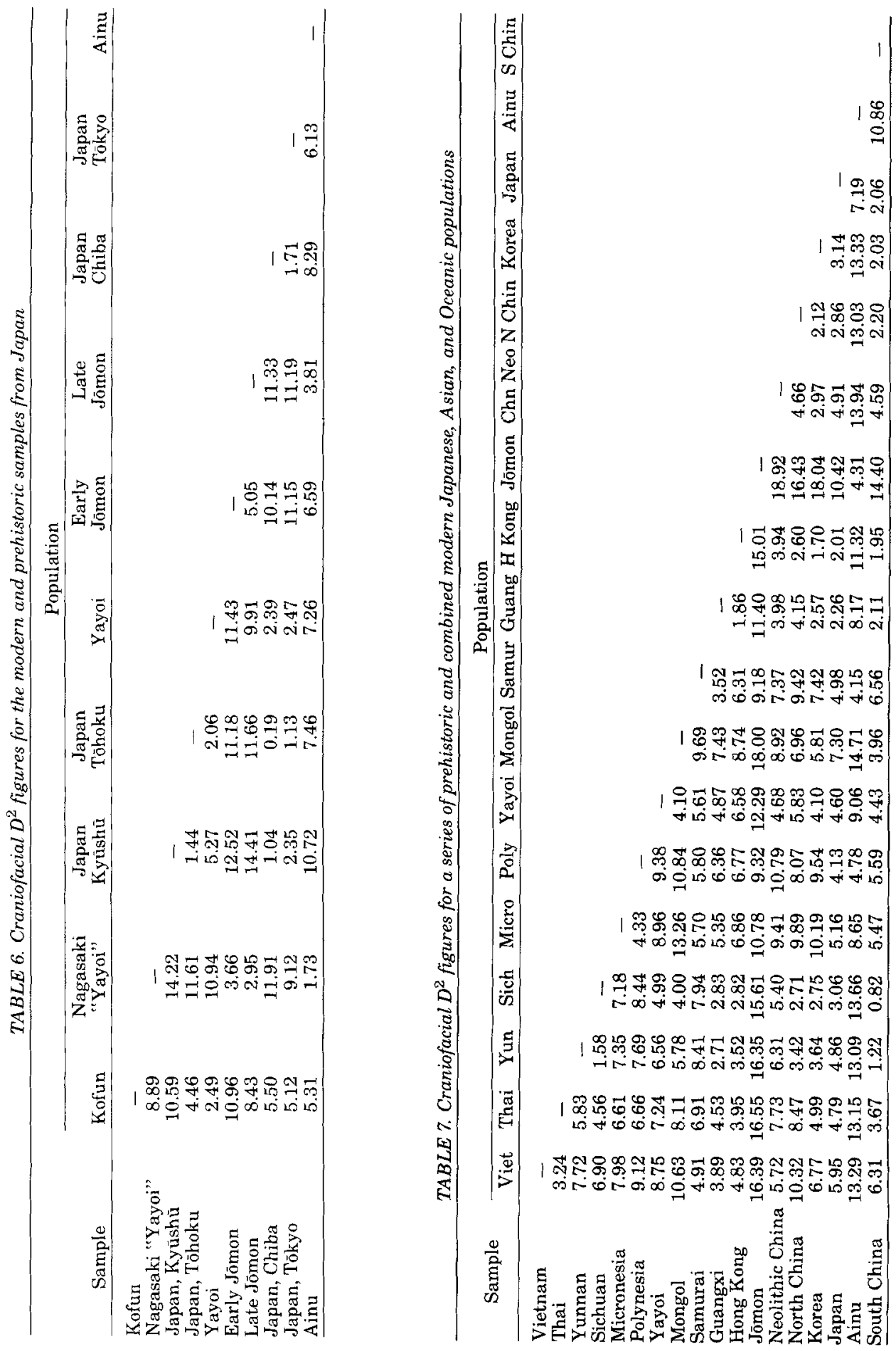

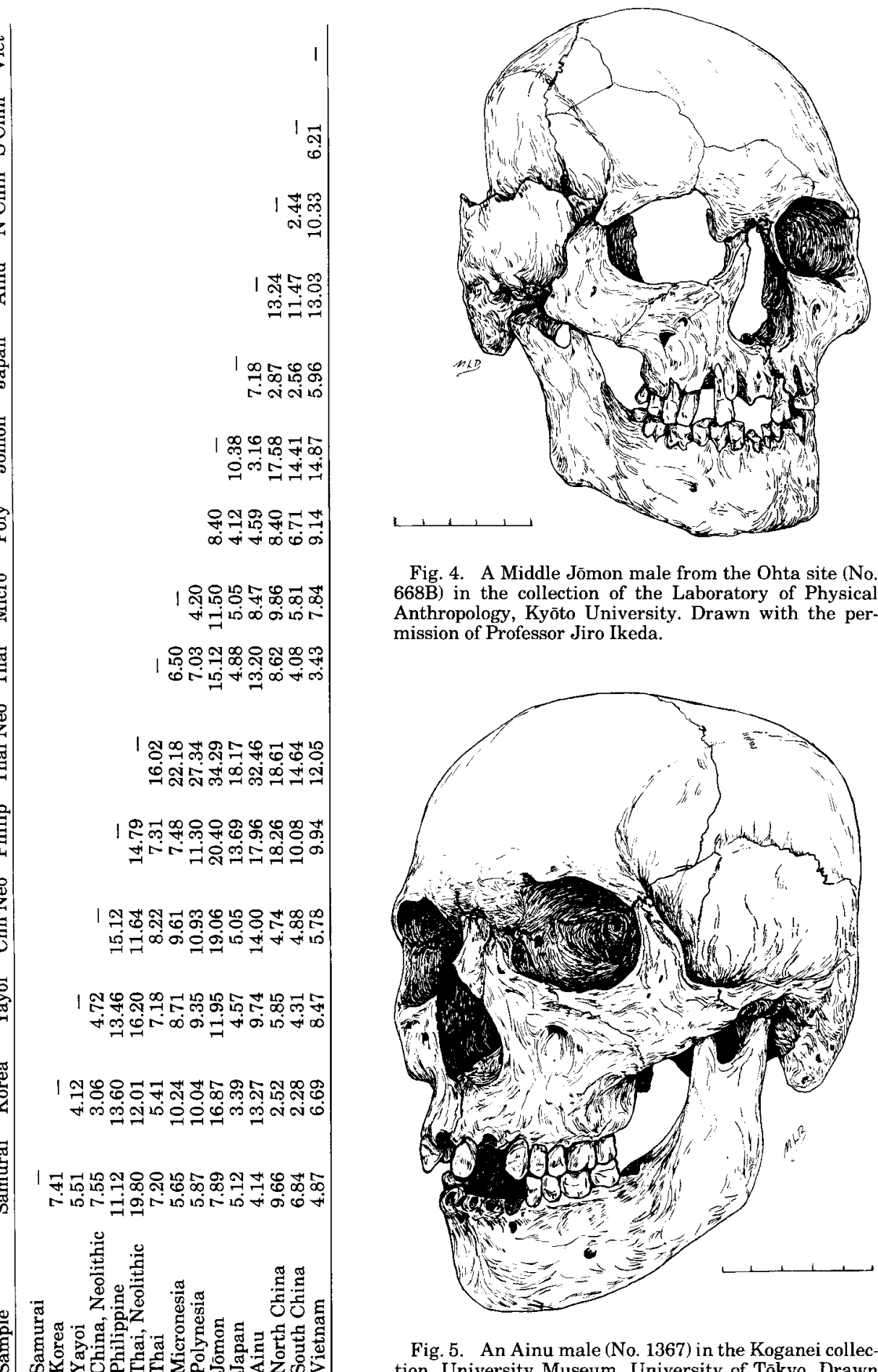

Fig. 4. A Middle Jōmon male from the Ohta site (No. 668B) in the collection of the Laboratory of Physical Anthropology, Kyōto University. Drawn with the permission of Professor Jiro Ikeda.

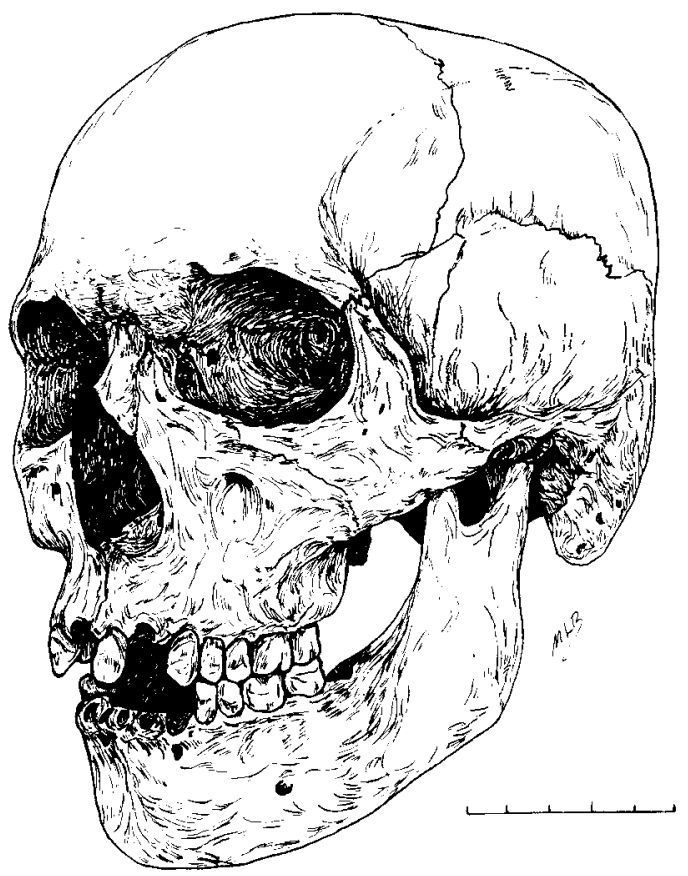

Fig. 5. An Ainu male (No. 1367) in the Koganei collection, University Museum, University of Tōkyo. Drawn with the permission of Professor Kazuro Hanihara. 


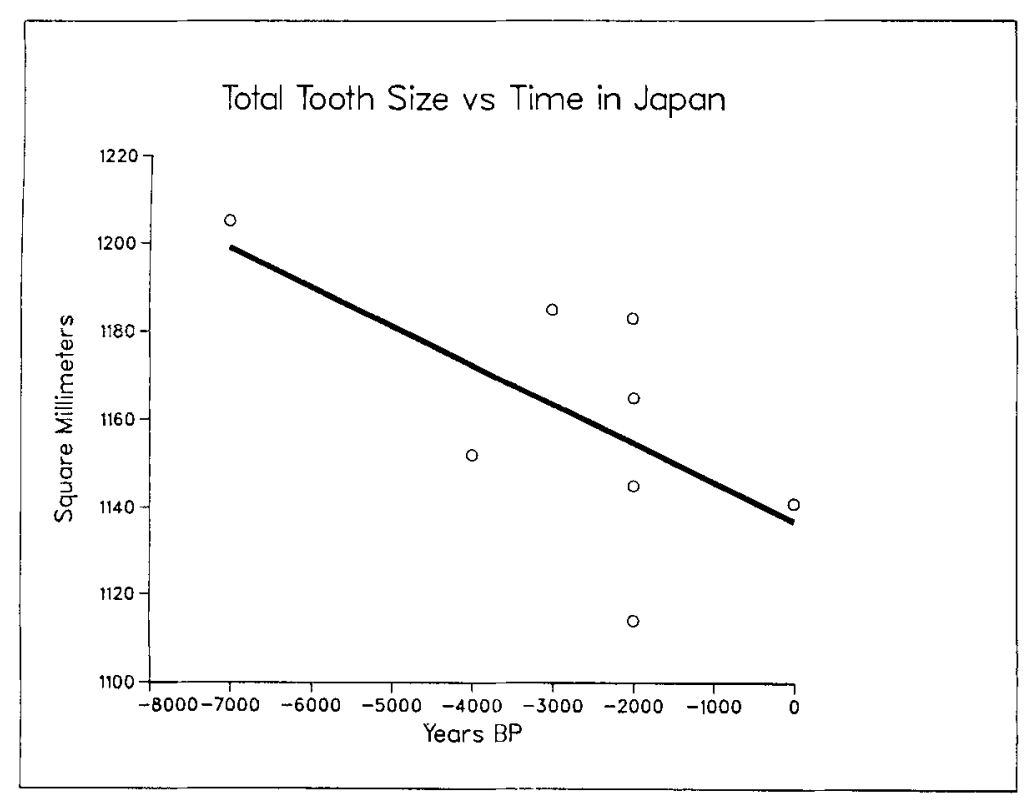

Fig. 6. The regression of total tooth size (TS) in situ in Japan from Early Jömon through the modern Ainu

chaeologically judged to be "Middle/Late" Jōmon was given a date of 3,500 B.P.-that is, between the rather crudely determined general dates for Middle and Late Jōmon. Since there was no way to get a direct date for the skeletal samples used, we had to adopt an arbitrary designation of time based on gen. eral archaeological assessment. If this is both arbitrary and lacking in the kind of precision for which we could wish, it is the best that could be done under the circumstances and we hope that it yields a reasonable model for the overall situation.

\section{DISCUSSION}

The principal points that emerge from our analysis are graphically displayed in Figures 1-3 and 6. A numerical version of these relationships and differences is recorded in the $D^{2}$ values in Tables $6-8$ and in the TS values in Table 2, but it is easiest to make our appraisals from the figures.

\section{Jōmon-Ainu continuity}

Figure 1 shows the relationships and distinctions between the samples from the Japanese islands alone. Two clear-cut and distinct clusters are represented-one including all the modern Japanese groups plus the Kofun and the Yayoi. From a craniological
(Brace et al., nd b). The combined measurements from which this was plotted can be found in Table 2 .

standpoint, the idea that the Kofun is simply a continuation of the Yayoi expressed in recent archaeological work (Barnes, 1986; H Kanaseki, 1986) is clearly substantiated. Both, in sequence, can clearly be regarded as the ancestors of the modern Japanese.

The second cluster in Figure 1 obviously lumps the various levels of Jōmon and the Ainu together and indicates that they have very little in common with the Yayoi rice farmers or the recent Japanese. This is very much in line with the view that emerged from the multivariate work of Howells (1966, 1986), Yamaguchi (1967), Dodo (1986), and Dodo and Ishida (1987). It is also very much in line with the assessment of dental morphology so elegantly demonstrated by Turner $(1976,1979,1983,1986$, in press; Turner and Hanihara, 1977) and in the nonmetric cranial treatment by Ossenberg (1986).

The one group in Figure 1 that may seem out of place is the sample labeled Nagasaki "Yayoi." As can be seen, this is included in the Ainu-Jōmon cluster and, morphologically, is obviously unrelated to the Yayoi in the modern Japanese cluster. Equally obvious is the fact that it does not cluster with the modern specimens from Kyūshū, most of which came from the dissecting rooms at $\mathrm{Na}$ gasaki University School of Medicine. 
This sample was excavated from northwestern Kyūshū between 1964 and 1969 by Professor Yoshiatsu Naito. It dates from the early to middle Yayoi and has been taken as proof that that the Yayoi biological configuration developed in situ right out of the preceding Jomon population as an example of "microevolution" (Suzuki, 1969; Naito, 1971; Akazawa, 1982b). However, the only reason it is called Yayoi at all is because of its association with Yayoi pottery. Unlike the Yayoi sites at Doigahama in western Honshū and around Fukuoka in the core of Kyūshū, where the subsistence economy was characterized by the practice of intensive, irrigated rice agriculture (Ushijima, 1954; Kanaseki and Kai, 1955; Kanaseki et al., 1960), the "Yayoi" people of northwestern Kyūshū were fishers and gatherers using a lithic technology and pursuing a subsistence strategy that was indistinguishable from that of the Jōmon people wherever they are found in Japan. Since they are skeletally indistinguishable from the Jōmon as well, we suggest that they were simply representatives of the indigenous Jōmon of Kyūshū who adopted the turned pottery of their Yayoi neighbors. When we use a lumped Jommon sample for our subsequent clusters (Figs. 2, 3 ), we feel justified in including these individuals to increase our sample size. We should note, however, that, whether they are included or not, the rest of the relationships displayed in those clusters are unaffected.

Certainly we feel that the arrangement visible in Figure 1 justifies our treatment of continuity from Early Jōmon right on up to the modern Ainu as an example of a continuing evolutionary lineage. If we consider the change in tooth size through time displayed within this lineage, we get the regression line portrayed in Figure 6. Since there is no comparable reduction in cranial dimensions over that same span of time, it has been considered as an example of the point where tooth size and body size have become notably "decoupled" in recent human evolution (Brace et al., 1987). The reduction in tooth size evidently proceeded at approximately the same rate ( $1 \%$ per thousand years) as it did in Europe and elsewhere in the post-Pleistocene. If, as has been suggested, this is the consequence of the adoption of improved food preparation practices, then it is no surprise to discover that the Jōmon-Ainu continuum in Japan not only shows the same trends found elsewhere but also that the smallest teeth in all of Asia are to be found in the Ainu of Japan: they, after all, are the direct descendants of the makers of the oldest pottery tradition in the world (Bleed, 1978; Ikawa-Smith, 1986), and it may well have been the use of pottery, which reduced the selective pressures maintaining usable tooth substance, that consequently allowed dental reduction to occur (Brace, 1978, 1988; Brace et al., 1987).

\section{Japan vis-á-vis Asia and Oceania}

We have taken the clustering of modern Japanese visible in Figure 1 as justification for lumping them together as a single group with a larger sample size for purposes of comparison with other mainland Asian and a couple of Oceanic samples. The results can be seen in Figures 2 and 3. Figure 2 shows the lumped modern Japanese, the lumped Jomon, the Ainu, and a group labeled Kamakura "Samurai" compared to a maximum diversity of mainland Asian samples and a combined Polynesian and a combined Micronesian set. The Kamakura Samurai are a most interesting case, and we shall defer treatment until the end of this Discussion. In Figure 2, as in Figure 1, two broad clusters can be seen: one that lumps the Ainu, the Jōmon, and the Samurai with the peoples of the island Pacific; and the other that includes the Yayoi and the modern Japanese with the peoples of mainland Asia. When these two broad clusters were first noted in a treatment of Asia, Oceania, and AustraloMelanesia, they were respectively referred to as the Jomon-Pacific cluster and the Main land-Asian cluster (Brace et al., in press).

In Figure 2, the Thai and the Vietnamese, although clearly related to each other, are the most remote members of the MainlandAsian cluster. Slightly less remote and also tied to each other are the Yayoi and the Mongols, something that may pique the interests of the linguists who posit an interior north Asian origin for the Korean and Japanese languages (Miller, 1986). When the small sample of Mongols is removed and the various Chinese are condensed as in Figure 3, however, the Yayoi form a tighter subcluster with the coastal Chinese, Koreans, Chinese Neolithic and modern Japanese, which certainly is in line with the visual impressions the observer gets when handling the material.

When this lumping of southern and coastal Chinese is made, as shown in Figure 3, the 


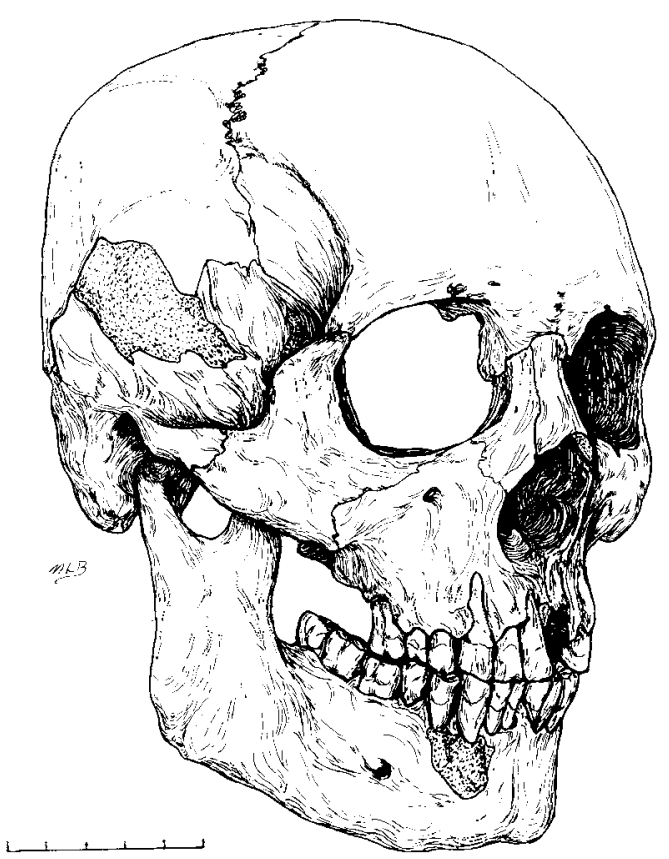

Fig. 7. A Yayoi male from the Doigahama site (No. 140) in the Department of Anatomy, Kyūshū University School of Medicine. Drawn with the permission of Professor Masafumi Nagai.

two main clusters still remain distinct, and the samples within them are arranged in a manner that is intuitively satisfying and easy to interpret. We added a Philippine sample, and it comes as close as the program allows to being a perfect intermediary between the Mainland-Asian and the JömonPacific cluster, which is just what it ought to do, the Philippines being right at the edge of the Pacific Basin with a long history of influence from the Asian mainland and yet populated by people who speak Austronesian languages related to those of the island $\mathrm{Pa}$ cific (Heine-Geldern, 1932; Beyer, 1947, 1948; Solheim, 1972; Hutterer, 1974; Jocano, 1975). The Vietnamese and Thai still remain something of an outlier of the Mainland-Asian cluster. The core of this cluster is composed of Koreans, coastal Chinese, Yayoi, the Chinese Neolithic, and the modern Japanese, with the north Chinese at another remove. The Jomon-Pacific cluster still retains the same members, but, in this manifestation, the Jomon themselves are the least tightly included, and the Ainu display a closer asso-

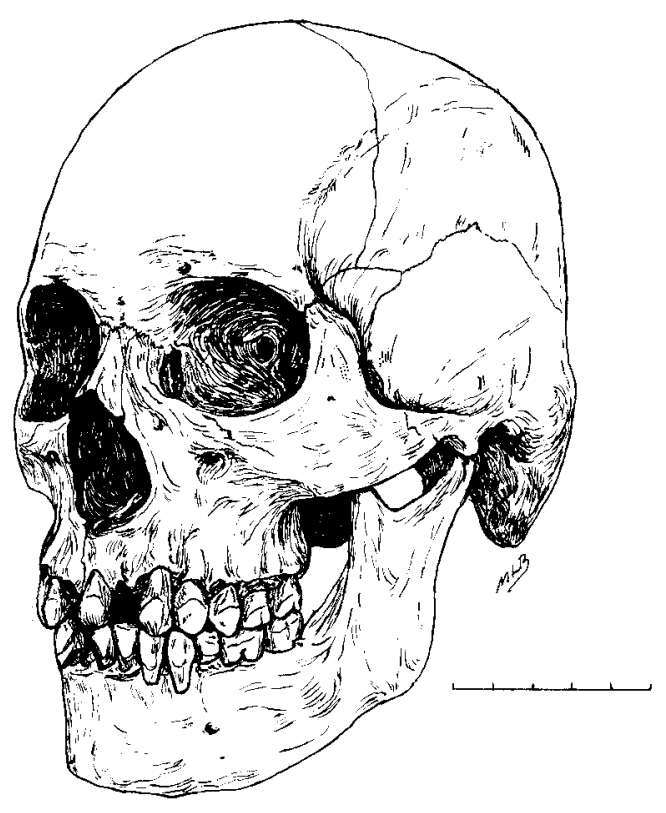

Fig. 8. A Japanese male from Tōkyo (No. 234) in the Koganei collection at the University Museum, University of Tokyo. Drawn with the permission of Professor Kazuro Hanihara.

ciation with the group we have called "Samurai."

\section{Yayoi-Kofun-Japanese continuity}

As can be seen in Figure 1, the various groups of modern Japanese cluster with the Kofun and the Yayoi, all of which are distinct from the Ainu-Jōmon cluster. When other Oceanic and mainland Asian groups are included, the Yayoi (Fig. 7) and the Japanese (Fig. 8) consistently are grouped with mainland samples-note their association with Koreans, southern Chinese and the Chinese Neolithic in Figure 3 and their continued separation from the cluster that includes Ainu, Jōmon, and Oceanic samples. The evidence seems to indicate that the Yayoi arrived as invaders-from southern Korea as many have suggested (Ohno, 1970; Befu, 1971; Bowles, 1977; Aikens and Higuchi, 1982)-and that they then replaced the indigenous Jōmon and went on via their Kofun descendants and give rise to the majority of the modern Japanese. 
While it has been said that "skeletal changes from the latter half of the end of the Jomon period to the Tomb period and on into modern times are not drastic enough to prove the conquest of Japan by a foreign race" (Ohno, 1970: p. 81), and more recent work has noted that "research on skeletal remains of the Yayoi period has not offered any substantial evidence for supporting this kind of a working model" (Akazawa, 1982b: p. 166; and see a similar view in $\mathrm{H}$ Kanaseki, 1986: p. 317), we suggest that our current analysis and the results of all previous systematically comparative work (Howells, 1966, 1986; Yamaguchi, 1967, 1982; Turner, 1976, 1979, 1983, 1986, in press; Dodo, 1986; Dodo and Ishida, 1987; Ossenberg, 1986) make precisely this interpretation the most likely model for the origins of the modern Japanese.

One of the objections from the archaeological standpoint is that there are no surviving indications of major armed conflict (Akazawa, 1982a,b). Our counter to this is that the replacement may simply have been accomplished by the reproductive success of the incoming Yayoi population. The most generous estimate for the total Jōmon population of Japan puts it at 120,000 people in all (Howells, 1986: p. 87). In contrast, the Yayoi had achieved a minimum of between one and two million within three hundred years of their arrival-again a minimum estimate (Tsukada, 1986: p. 50). This yields a Yayoi numerical superiority of 10:1. And if we take the model of Aoki and Omoto (1980), the terminal Jomon population was 14,000 all told vs. a total of 2,800,000 for the Yayoi-a Yayoi superiority of 200:1. Any way it is calculated (and note the various simulations proposed by Hanihara, 1987), the Yayoi achieved an overwhelming numerical superiority in a very short space of time.

We grant that Aoki and Omoto prefer to regard the Yayoi population level as having been achieved as the result of an increase in numbers by acculturated Jōmon people, but it could just as well have been a comparable increase in an immigrant population. In fact, this is exactly what has occurred on the island of Hokkaido only within the last century, and we suggest that this was simply the last act in the triumph of the Japanese expansion which began in the west with the Yayoi invasion of 300 B.C. Furthermore, such a model is the only way we can account for the nature of the clusters shown in Figures 1-3.

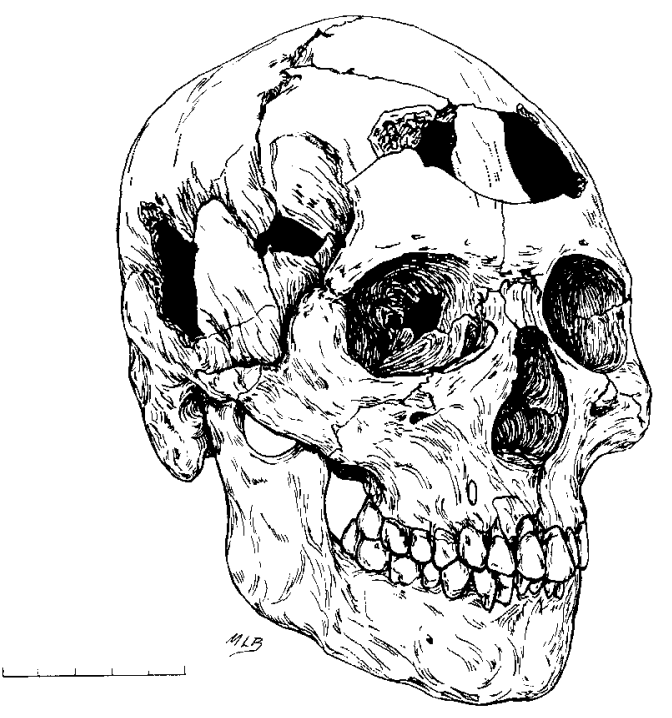

Fig. 9. A "Samurai" male, one of the victims of the battle at Kamakura City in 1333. No. 190 in the University Museum, University of Tōkyo. Drawn with the permission of Professor Kazuro Hanihara.

We should also note that there is indeed legendary and historical evidence for a clash between those coming from the western part of Japan with the resident populace farther east. The chronicles of the emergence of feudal Japan demonstrate an important phase of this long-playing drama, and we present a key aspect of this when we consider the emergence of the Samurai ideal.

\section{The source of the Samurai}

The sample that we have chosen to call "Samurai" (Fig. 9) is such an interesting example of the intersection of the historical and the biological that we shall take some time to consider it. The skeletons themselves are the remains of the victims of the attack on Kamakura City by Nitta Yoshisada in the summer of A.D. 1333 (Suzuki, 1956; Sansom, 1961). That particular battle may have marked the end of the Kamakura Shogunate (1185-1333) per se, but the governing structure that had been set up by its founder, Minamoto Yoritomo, was so entrenched by that time that it set the pattern for the military rule of Japan for the succeeding six hundred years (Murdoch, 1903; Asakawa, 1933; Sansom, 1958; Shinoda, 1960).

When Yoritomo set up the model in A.D. 1185 for what was to be the continuing Sho- 
gunate, he did so with an army of retainers whom he had brought with him from "the east," where his forebears had previously served as frontier administrators (Asakawa, 1933; Storry, 1978). As was so often the case when the emperor in Kyōto sent administrators to try to pacify the unruly inhabitants at the eastern frontier, the armies raised to accomplish this task were often recruited from the very residents the provincial administration was charged with controlling. The latter were traditionally referred to in Japanese historical accounts as "Emishi" (e.g., in Sansom, 1958, 1961), a derogatory term that was replaced by "Ainu" following the Meiji restoration in 1868. Consistent with this tradition, Yoritomo assembled a following with promises of land and emoluments, and it was with these expectations that they accompanied him to Kamakura in 1180 whence he launched the campaigns that brought him undisputed military power in A.D. 1185. The "east" from which his army was recruited was the Kantō district, the area surrounding what is now Tōkyo, a region famous for the warlike qualities of its inhabitants (Sansom, 1958; Shinoda, 1960; Storry, 1978). It was also the area where much of the unrest was caused by contention for control with the Ainu, who were still a force in northeastern Japan, and it is a good guess that Yoritomo, by recruiting from the very population that was the source of that contention, basically acquired an army that was in large part of Ainu (Emishi) origin. Is it any surprise, then, that the descendants of his supporters who lost their lives in the battle at Kamakura in 1333 should so consistently fall into the Ainu-Jōmon cluster as they do in Figures 2 and 3 ?

To be sure, Suzuki specifically regards them as a local variant of modern Japanese and denies that they could be Ainu (Suzuki, 1956) even while he mentions certain traits that are more characteristically Ainu than Japanese. In our analysis also they fall into the Japanese cluster under some circumstances. When we used untransformed measurements, they fell into the Japanese cluster when we included bizygomatic breadth and into the Ainu cluster when we left it out. And when we leave out Mainland Asian and Oceanic samples as in Figure 1, they fall in with the Yayoi and the Kofun. It would seem that under some circumstances they can be regarded as Ainu, and under other conditions they rank as Japanese: but this is just what we should expect for a population that had been right at the frontier between those two contending elements for a prolonged period of time.

All of this may well have had some impact on the physical characteristics of people of different status in Japan as well as on Japanese ideals in regard to personal appearance. The effect of Yoritomo's brief regime was to give an enduring measure of power and prestige to a warrior class of eastern origin (Asakawa, 1933; Sansom, 1958, 1961; Shinoda, 1960; Storry, 1978). In turn, the form of their facial features became a kind of highstatus criterion and could very well account for the fact that the "Samurai" stereotype idealized in Japanese art is so unlike the average appearance of the typical person encountered on the Japanese street-or in the medical-school dissecting rooms from Kyūshū to Tōhoku. The kabuki actors, courtesans, and samurai portrayed so often in paintings, screens, kites, and wood block prints (cf. Streeter, 1974; Neuer et al., 1979; Halloran, 1986) all tend to display the elevated nasal skeleton, the slight swelling at the center of the brow, the point on the chin, and the flat-sided cheeks that set apart Ainu form from that of the typical Japanese. The first European to write a serious history of Japan, the seventeenth-century German physician Engelbert Kaempfer, also noted that a "higher, more European-like nose" was to be found among the nobility and important state officials (Kaempfer, 1964 [17771779]: p. 110, although the earlier English translation of 1727 only mentions that the "countenance" in the "noblest families, of the Princes and Lords of the Empire" was "more like Europeans" 1906 [1727]: p. 151).

One could even suggest that the lighter skin color documented for the higher social classes in Japan (Hulse, 1967) had its origin in the same manner, for the early observers often remarked that skin color in the Ainu was noticeably lighter than in the Japanese (Batchelor, 1892). Even the characteristic tonsure of the samurai, with the shaved section at the front, is recorded by earlier observers to have been an Ainu custom (Batchelor, 1892; Sternberg, 1929), although it is conceivable that this could have been copied by the Ainu from their oppressors. Still, it is just possible that it might be part of the legacy that the samurai received from the obviously Ainu part of their ancestry. The Jōmon-Ainu legacy might also be the 
source of those culinary traditions wherein the Japanese differ to such a striking extent from the Chinese and, in fact, from all the other cuisines of Asia (cf. Lin and Lin, 1972; Solomon, 1976; Tsuji, 1980).

There is more than a little irony in this whole picture: where the Ainu, so looked down upon in the traditional Japanese conception of the social spectrum (Takaaki, 1987), have had a genetic effect on the ruling classes of Japan that would be completely unexpected for a conquered and despised people presumed to have been exterminatedand whose very prior existence has been denied for much of Japan. (Cf. the synopsis of these denials in Ohno, 1970.)

\section{CONCLUSIONS}

The casual observer of the features of the modern Japanese invariably notes that in general they share so much in common with the other inhabitants of eastern Asia that it is not possible to make broad regional or national distinctions on the basis of an assessment of those features alone. Occasionally a particularly observant appraiser may remark that sometimes there are nuances of brow form, eye socket shape, nasal bridge elevation, and chin-and-jaw definition that are not shared with other well-known Asian populations. The results of our multivariate analysis of a set of craniofacial variables are quite in line with the conclusions of that hypothetical "casual observer," as are those of previous, if less extensive, studies. Biologically, the Japanese evidently are closely similar to continental Asians from Korea and throughout coastal, southern, and western China. From our treatment of the available evidence from all of the various major groups to inhabit the Japanese islands past and present, and a sampling of continental Asian and Oceanic populations, these are the points with which we can conclude:

1. The modern Japanese belong to what can be termed the Mainland-Asian cluster.

2. The advent of this Mainland-Asian manifestation in Japan was the immigration in 300 B.C. of the Yayoi rice agriculturalists, and its modern representatives reflect little from the indigenous Jomon inhabitants of the Japanese archipelago.

3. The Jomon fishing-hunting-collecting people of prehistoric Japan are the direct ancestors of the Ainu, once spread throughout the islands but now restricted to dwindling numbers only on Hokkaidō.
4. The dental reduction demonstrable for the continuing line from Early Jōmon to the modern Ainu has been proceeding at the same rate as the one documented for Europe, the Middle East, and elsewhere in the world during the post-Pleistocene. Since we suggest that this reduction was the result of the relaxation of the forces of selection consequent upon the use of pottery in food preparation, and since Jomon pottery is the oldest in Asia and perhaps the world, it is consistent to note that the Ainu in fact have the smallest teeth in all of modern Asia.

5. Jōmon form is closely allied to that visible in Polynesia and Micronesia, constituting an important part of and perhaps a point of origin for what can be called the Jommon-Pacific cluster. This in turn is essentially unrelated to the Mainland-Asian cluster.

6. Because of the actual course of history and the regional shifts of power that occurred as the feudal system emerged in Medieval Japan, the genetic characteristics derived from the Jommon-Ainu continuum came to constitute a significant part of the biological makeup of the dominant military class. This has been unconsciously perpetuated in the artistic canons used to depict Samurai form in the various manifestations of Japanese graphic art.

7. To the extent that these elements are part of modern Japan, their physical heritage may be said to depart from the Mainland-Asian configuration and to reflect a survival of the aboriginal but otherwise unrelated JōmonPacific set of characteristics. The biological relationship between the Jōmon-to-Ainu line in Japan and the peoples of island Oceania should lend credence to the possibility of an Austronesian element or "substratum" in the Japanese language, but this is a matter for separate study by a different group of scholars.

\section{ACKNOWLEDGMENTS}

The research on which this project is based was refused support by the National Science Foundation in 1973, 1981, and 1985. Partial support was provided by the Horace $H$. Rackham School of Graduate Studies at the University of Michigan in 1973, 1977, 1980, and 1983; by the University of Auckland, Auckland, New Zealand, in 1973-1974; by the Committee on Scholarly Communication with the People's Republic of China, National Academy of Sciences, in 1980 and 1985; by the University of Michigan Museum of 
Anthropology Field Research Fund in 1984, 1985, and 1986; by the L.S.B. Leakey Foundation in 1986; and by Diana Blaban Holt in 1987. Essential assistance has also been given by Mark A. Gordon and Chacma, Inc., of New York, NY; by Professor Hiroshi Kanaseki, Tenri University, Nara; by Professor Takeshi Kanaseki, Kyūshu University; by Dr. Gina L. Barnes, Cambridge University; by Professors Ben R. Finney and Wilhelm G. Solheim, II, University of Hawaii; by Roger C. and Peggy L. Brace of Ann Arbor, MI; by G. Brace of Nanterre, France; and by Lono. Important financial support was also provided by the late $\mathrm{E}$. $\mathrm{B}$. Hoagland and by the late Professor and Mrs. G. W. Brace.

For access to and help in the various collections under their care, we are grateful to Professor Kazuro Hanihara, University of Tōkyo; Dr. Jean-Louis Heim, Musée de l'Homme, Paris; Professor Jiro Ikeda, Kyōto University; Professor Toshihiro Ishii, Tōhoku University; Professor Nina Jablonski, University of Hong Kong; Professors Kohei Mitsuhashi and Yukio Dodo, Sapporo Medical College; Professor Masafumi Nagai, Kyūshū University; Professor Yoshiatsu Naito, Nagasaki University; Professor Michael Pietrusewsky, University of Hawaii; Professor Shao Xiang-qing, Anthropology Section, Department of Biology, Fudan University, Shanghai, People's Republic of China; Dr. Yoshihiko Sinoto, B.P. Bishop Museum; Dr. Ian Tattersall, American Museum of Natural History; Dr. Wei Boyuan, Guangxi Medical College; and Professor Wu Jukang, Professor Wu Xinzhi and Zhang Zhenbiao, Institute of Vertebrate Paleontology and Paleoanthropology, Academia Sinica, Beijing, People's Republic of China.

We are also grateful to Charles L. Brace, Professor Kazuro Hanihara, Professor Frederick S. Hulse, and Margot Massey for references, advice, and guidance in some of the more difficult aspects of Japanese history. We are also indebted to Dr. Gina L. Barnes, Department of Archaeology and Anthropology, Cambridge University, and to Professor Karl L. Hutterer and Masas Nishimura, Museum of Anthropology, University of Michigan, Ann Arbor, for guidance in matters of Japanese prehistory; and to Professor Hitoshi Watanabe, Waseda University, Tōkyo, and Professor Masakazu Yoshizaki, Hokkaidō University, Sapporo, for valuable perspectives on matters pertaining to the Ainu, past and present.

\section{LITERATURE CITED}

Aikens CM, and Higuchi T (1982) Prehistory of Japan. New York: Academic Press.

Akazawa T (1982a) Jomon people subsistence and settlements: Discriminatory analysis of the later Jomon settlements. J. Anthropol. Soc. Nippon [Suppl.]90:55-76.

Akazawa $\mathrm{T}$ (1982b) Cultural change in prehistoric Ja pan: Receptivity to rice agriculture in the Japanese archipelago. In Advances in World Archaeology. Aca demic Press, Orlando, Fla., pp. 151-211.

Akazawa T (1986) Discriminant function analysis of later Jōmon settlements. In RJ Pearson, GL Barnes and KI Hutterer (eds.): Windows on the Japanese Past: Stud ies in Archaeology and Prehistory. Ann Arbor: Center for Japanese Studies, University of Michigan, pp. 279 292.

Aoki $\mathrm{K}$ and Omoto $\mathrm{K}$ (1980) An analysis of the ABO gene frequency cline in Japan: A migration model. J. Anthropol. Soc. Nippon 88: 109-122.

Asakawa K (1933) The founding of the Shogunate by Minamoto-No-Yoritomo. Seminarium Kondakovianum 6: $109-129$.

Aston WG (translator) (1896[1956]) Nihongi: Chronicles of Japan from the Earliest Time to AD 697 (reprint of the 1896 edition). London: George Allen and Unwin, Ltd.

Barnes GL (1986) Introduction: The Yayoi and Kofun. In RJ Pearson, GL Barnes, and KL Hutterer (eds.): Windows on the Japanese Past: Studies in Archaeology and Prehistory. Ann Arbor: Center for Japanese Studies, University of Michigan, pp. 313-315.

Batchelor J (1892) The Ainu of Japan: The Religion, Superstitions, and General History of the Hairy Aborigines of Japan. London: The Religious Tract Society.

Befu H (1971) Japan: An Anthropological Introduction. San Francisco: Chandler.

Beyer HO (1947) Outline review of Philippine archaeol ogy by islands and provinces. Philippine J. Sci. 77:205374.

Beyer HO (1948) Pacific and East Asian Archaeology and Its Relation to the Origin of the Pacific Islands Population. National Research Council of the Philippines, Quezan City, Bulletin No. 29

Bickmore AS (1868) The Ainos, or hairy men of Yesso. Am. J. Sci. Arts 44:353-361.

Birdsell JB (1951) The problems of the Americas as viewed from Asia. In WS Laughlin (ed.): Papers on the Physical Anthropology of the American Indian. New York: The Viking Fund, pp. 1-68.

Birdsell JB (1967) Preliminary data on the trihybrid origin of the Australian aborigines. Archaeol. Phys. Anthropol. Oceania 2: 100-155.

Bleed P (1978) Origins of the Jōmon technical tradition. Asian Perspect. 19:107-115.

Bowles GT (1977) The People of Asia. London: Weidenfeld and Nicolson.

Brace CL (1978) Tooth reduction in the Orient. Asian Perspect. 19:203-219.

Brace CL (1979a) Biological parameters and Pleistocene hominid life-ways. In IS Bernstein and EO Smith (eds.): Primate Ecology and Human Origins: Ecological Influences on Social Organization. New York: Garland Press, pp. 263-289.

Brace CL (1979b) Krapina, "classic" Neanderthals, and the evolution of the European face. J. Hum. Evol. 8:527-550.

Brace CL (1980) Australian tooth-size clines and the 
death of a stereotype. Curr. Anthropol. 21:141-164.

Brace CL (1988) The Stages of Human Evolution. 3rd ed. Englewood Cliffs, New Jersey: Prentice-Hall.

Brace CL, and Hinton RJ (1981) Oceanic tooth size vari ation as a reflection of biological and cultural mixing Curr. Anthropol. 22:549-569.

Brace CL, and Nagai M (1982) Japanese tooth size, past and present. Am. J. Phys. Anthropol. 59:399-411.

Brace CL, Rosenberg KR, and Hunt KD (1987) Gradual change in human tooth size in the late Pleistocene and post Pleistocene. Evolution 41:705-720.

Brace CL, and Ryan AS (1980) Sexual dimorphism and human tooth size differences. J. Hum. Evol. 9:417-435.

Brace CL, Shao X-q, and Zhang Z-b (1984) Prehistoric and modern tooth size in China. In FH Smith and F Spencer (eds.): The Origins of Modern Humans: A World Survey of the Fossil Evidence. New York: Alan R. Liss, Inc., pp. 485-516.

Brace CL, Brace ML, Dodo Y, Leonard WR, Li Y, Shao $X-q$, Sangvichien $S$, and Zhang $Z$ (in press) Micronesians, Asians, Thais and relations: A craniofacial and odontometric perspective. J. Micronesian Soc.

Busk G (1867) Description of an Aino skull. Trans. Ethnol. Soc. Lond. 6:109-111.

Chamberlain AF (1912) The Japanese race. J. Race Dev. $3: 176-187$

Chew JJ (1978) The prehistory of the Japanese language in the light of evidence from the structures of Japanese and Korean. Asian Perspect. 19:190-200.

Crawford GW, and Yoshizaki M (1987) Ainu ancestors and prehistoric Asian agriculture. J. Archaeol. Sci. 14:201-213.

Dodo Y (1986) Metrical and non-metrical analyses of Jomon crania from eastern Japan. In T Akazawa and CM Aikens (eds.): Prehistoric Hunter-Gatherers in Japan. The University of Tokyo, The University $\mathrm{Mu}$ seum, Bull. No. 27, pp. 137-161.

Dodo Y, and Ishida H (1987) Incidences of nonmetric cranial variants in several population samples from East Asia and North America. J. Anthropol. Soc. Nippon 95:161-177.

Fox DJ, and Guire KE (1976) Documentation for MIDAS, 3rd ed. Ann Arbor: Statistical Research Laboratory, University of Michigan.

Halloran FM (1986) Japan's shining prince turns 1000 NY Times Book Rev. Nov. 30:1,41.

Hanihara K (1970) Mongoloid dental complex in the deciduous dentition with special reference to the dentition of the Ainu. J. Anthropol. Soc. Nippon 78:3-17.

Hanihara K (1976) Statistical and Comparative Studies of the Australian Aboriginal Dentition. The University of Tokyo: The University Museum, Bulletin No. 11.

Hanihara K (1977) Dentition of the Ainu and Australian aborigines. In AA Dahlberg and TM Graber (eds.): Orofacial Growth and Development. The Hague: Mouton, pp. 195-200.

Hanihara K (1987) Estimation of the number of early migrants to Japan: A simulative study. J. Anthropol. Soc. Nippon 96:391-403.

Harvey RG, Tills D, Mourant AE, Giblett ER, Cleve H, Bearn AG, and McConnell RB (1978) Blood groups, serum proteins and enzymes of the Ainu of Hokkaido. Hum. Biol. 50:425-450.

Heine-Geldern R (1932) Urheimat und früheste Wanderungen der Austronesier. Anthropos 27:543-619.

Hooton EA (1946) Up From the Ape. 2nd ed. New York: Macmillan.
Hovells WW (1966) The Jomon population of Japan. A study by discriminant analysis of Japanese and Ainu crar. a. Papers Peabody Mus. Archaeol. Ethnol. 57:143.

Howells WW (1973) The Pacific Islanders. New York: Scribner.

Howells WW (1986) Physical anthropology of the prehistoric Japanese. In RJ Pearson, GL Barnes, and KL Hutterer (eds.): Windows on the Japanese Past: Studies in Archaeology and Prehistory. Ann Arbor: Center for Japanese Studies, University of Michigan, pp. 8599

Howells WW (in press) Micronesia to macromongolia: Micro-Polynesian craniometrics and the Mongoloid population complex. J. Micronesian Soc.

Hulse FS (1967) Selection for skin color among the Jap anese. Am. J. Phys. Anthropol. 27:143-156.

Hutterer KL (1974) The evolution of Philippine lowland societies. Mankind 9:287-299.

Ikawa-Smith F (1980) Current issues in Japanese ar chaeology. Am. Sci. 68:134-145.

Ikawa-Smith F (1982) Early prehistory of the Americas as seen from Northeast Asia. In JE Ericson, RE Taylor, and R Berger (eds.): Peopling of the New World. Los Altos, Cal.: Ballena Press, pp. 15-33.

Ikawa-Smith F (1986) Late Pleistocene and early Holocene technologies. In RJ Pearson, GL Barnes, and KL Hutterer (eds.): Windows on the Japanese Past: Studies in Archaeology and Prehistory. Ann Arbor: Center for Japanese Studies, University of Michigan, pp. 199 216.

Jocano FL (1975) Philippine Prehistory: An Anthropological Overview of the Beginnings of Filipino Society and Culture. Quezon City: Diliman, Philippine Center for Advanced Studies, University of the Philippines System.

Kaempfer E (1906) The History of Japan, Vol. I. Translated by J. W. Scheuzer, reprint of the 1727 edition. Glasgow: James J. MacLehose.

Kaempfer E (1964) Geschichte und Beschreibung von Japan, Vol. I. Edited by Christian Wilhelm Dohm, reprint of the $1777-1779$ edition. Stuttgart: F.A. Brockhaus.

Kagawa M (1973) Primitive agriculture in Japan: Latest Jōmon agricultural society and means of production. Asian Perspect. 16:1-15.

Kanaseki $H$ (1986) The evidence for social change between the early and middle Yayoi. In RJ Pearson, GL Barnes, and KL Hutterer (eds.): Windows on the Japanese Past: Studies in Archaeology and Prehistory. Ann Arbor: Center for Japanese Studies, University of Michigan, pp. 317-333.

Kanaseki T, and Kai Y (1955) On the skeletal remains from the urn-burial sites of Yayoishiki-age at Onobaru and Akinari, Ukiha-gun, Fukuoka-ken. Q. J. Anthropol. 2:72-92, (English summary, pp. 72-73.)

Kanaseki T, Nagai M, and Sano H (1960) Craniological studies of the Yayoi-period ancients excavated at the Doigahama site, Yamaguchi prefecture. Q. J. Anthropol. [Suppl.] 7:1-36.

Koganei Y (1894) Beiträge zur physischen Anthropologie der Ainu. I. Untersuchungen am Skelet. Mitt. Med. Fac. Kaiser. Jpn. Univ. II:1-249, 404.

Koganei Y (1927) Zur Frage der Abstammung der Aino und ihre Verwandtschaft mit anderen Völkern. Anthropol. Anzeig. 4:201-207.

Koganei Y (1937) Zur Frage des "Südlichen Elementes" in Japanischen Volke. Z. Rassenk. 5:123-130. 
Levin MG (1961) The ethnic history of Japan. Asian Perspect. 5:134-137.

Lin HJ, and Lin TF (1972) Chinese Gastronomy. New York: Pyramid Publications.

Lu DJ (1974) Sources of Japanese History. New York: McGraw-Hill

Miller RA (1971) Japanese and Other Altaic Languages. Chicago: University of Chicago Press.

Miller RA (1974) The origins of Japanese. Monument. Nippon 29:93-102.

Miller RA (1980) Origins of the Japanese Language. Seattle: University of Washington Press.

Miller RA (1986) Linguistic evidence and Japanese prehistory. In RJ Pearson, GL Barnes and KL Hutterer (eds.): Windows on the Japanese Past: Studies in Archaeology and Prehistory. Ann Arbor: Center for Jap anese Studies, University of Michigan, pp. 101-120.

Mitsuhashi K (1967) The distribution of Japanese fingerprints. Acta Crim. Jpn. 33:160-165.

Morse ES (1878) Traces of an early race in Japan. Pop. Sci. Monthly 14:257-266.

Mourant AE (1980) Linkage, equilibrium and disequilibrium in human population studies. Ann. Hum. Biol 71:109-114.

Murayama S (1972) Review of Japanese and Other Altaic Languages by RA Miller. Monument. Nippon $27: 463-467$

Murayama S (1976) The Malayo-Polynesian component in the Japanese language. J. Jpn. Stud. 2:4113-436.

Murdoch $J$ (1903) A History of Japan During the Century of Early Foreign Intercourse (1542-1651). Kobe: Published at the Office of the Chronicle.

Naito Y (1971) On the human skeletons of Yayoi period excavated at the sites in North-Western Kyushu. J. Anthropol. Soc. Nippon 79:236-248, (English sum. mary, p. 246)

Neuer R, Libertson H, and Yoshida S (1979) Ukiyo-E; 250 Years of Japanese Art. New York: Gallery Books.

Ohno S (1970) The Origin of the Japanese Language. Tokyo: Kokusai Bunka Shinkokai.

Omoto K (1970) The distribution of polymorphic traits in the Hidaka Ainu. I. Defective colour vision, PTC taste sensitivity and cerumen dimorphism. J. Fac. Sci. Tokyo Univ. Sect. V Anthropol. 3:337-355.

Omoto K (1972) Polymorphisms and genetic affinities of the Ainu of Hokkaido. Hum. Biol. Oceania 1:278-288.

Omoto K, and Harada H (1975) The distribution of polymorphic traits in the Hidaka Ainu. II. Red cell enzyme and serum protein groups. J. Fac. Sci. Tokyo Univ. Sect. V Anthropol. 4:171-211.

Omoto K, and Misawa S (1976) The genetic relations of the Ainu. In RL Kirk and AG Thorne (eds.): The Origin of the Australians. Atlantic Highlands, New Jersey: Humanities Press, pp. 365-376.

Ossenberg NS (1986) Isolate conservatism and hybridization in the populations history of Japan: The evidence of nonmetric cranial traits. In T Akazawa and CM Aikens (eds.): Prehistoric Hunter-Gatherers in Japan. Tokyo: University of Tokyo, The University Museum, Bulletin No. 27, pp. 199-215.

Pearson RJ (1986) Introduction, The Jömon. In RJ Pearson, GL Barnes, and KL Hutterer (eds.): Windows on the Japanese Past: Studies in Archaeology and Prehistory. Ann Arbor: Center for Japanese Studies, University of Michigan, pp. 219-221.

Pietrusewsky M (1971) Application of distance statistics to anthroposcopic data and a comparison of results obtained with those obtained by using discrete traits of the skull. Archaeol. Phys. Anthropol. Oceania 6:21 33.
Pietrusewsky M (1979) Craniometric variation in Pleis tocene Australian and more recent Australian and New Guinea populations studies by multivariate proce dures. Canberra: Australian Institute of Aboriginal Studies, Occasional Papers in Human Biology, Vol. 2, pp. 83-123.

Pietrusewsky M (1981) Cranial variation in early metal age Thailand and Southeast Asia studied by multivariate procedures. Homo 32:1-26.

Pietrusewsky M (1983) Multivariate analysis of New Guinea and Melanesian skulls: A review. J. Hum. Evol 12:61-76.

Pietrusewsky M (1984) Metric and non-metric cranial variation in Australian aboriginal populations com pared with populations from the Pacific and Asia. Can berra: Australian Institute of Aboriginal Studies, Occasional Papers in Human Biology, Vol. 3, pp. 1113.

Pietrusewsky $\mathbf{M}$ (in press) Craniometric variation in $\mathbf{M i}$ cronesia and the Pacific: A multivariate study. J. Micronesian Soc.

Sansom G (1958) A History of Japan to 1334. Stanford, Cal.: Stanford University Press.

Sansom G (1961) A History of Japan 1334-1615. Stan ford, Cal.: Stanford University Press.

Shinoda M (1960) The Founding of the Kamakura Sho gunate, 1180-1185. New York: Columbia University Press.

Sibley CG, and Ahlquist JE (1984) The phylogeny of the hominoid primates, as indicated by DNA-DNA hybrid ization. J. Mol Evol. 20:2-15.

Sibley CG, and Ahlquist JE (1986) Reconstructing bird phylogeny by comparing DNA's. Sci. Am. 254:82-92.

Sneath PHA, and Sokal RP (1973) Numerical Taxonomy: The Principles and Practice of Numerical Classifica tion. San Francisco: Freeman.

Solheim WG II (1972) Prehistoric pottery of Southeast Asia. In N Barnard (ed.): Early Chinese Art and Its Possible Influence in the Pacific Basin. New York: In tercultural Arts Press, pp. 508-532.

Solomon C (1976) The Complete Asian Cooking. New York: McGraw-Hill.

Sternberg L (1929) The Ainu problem. Anthropos 24.755 799.

Storry R (1978) The Way of the Samurai. New York Galley Press.

Streeter T (1974) The Art of the Japanese Kite. Tokyo: Weatherhill.

Suzuki H (1956) Medieval Japanese skeletons from the burial site at Zaimokuza, Kamakura City. Tokyo: Iwanami Shoten for the Anthropological Society of Nippon, English abstract, pp. 171-190.

Suzuki H (1969) Microevolutionary changes in the Japanese population from the prehistoric age to the present day. J. Fac. Sci, Univ. Tokyo Sect. V Anthropol. 3:279 309 .

Takaaki M (1987) Ainu, the invisible minority. Jpn. Q. 34:143-148.

Tsuji S (1980) Japanese Cooking: A Simple Art. New York: Kodansha.

Tsukada M (1986) Vegetation in prehistoric Japan: The last 20,000 years. In RJ Pearson, GL Barnes, and KL Hutterer (eds.): Windows on the Japanese Past: Studies in Archaeology and Prehistory. Ann Arbor: Center for Japanese Studies, University of Michigan, pp. 1156.

Turner CG II (1976) Dental evidence on the origins of the Ainu and Japanese. Science 193:911-913.

Turner CG II (1979) Dental anthropological indications of agriculture among the Jomon people of central Ja- 
pan. Am. J. Phys. Anthropol. 51:619-636.

Turner CG II (1983) The origin of the Ainu. Q. Rev. Archaeol. 4:11-12.

Turner CG II (1985a) The dental search for Native American origins. In R Kirk and E Szathmary (eds.): Out of Asia: Peopling the Americas and the Pacific. Canberra: J. Pacific Hist. pp. 31-78.

Turner CG II (1985b) Expression count: A method for calculating morphological dental trait frequencies by using adjustable weighting coefficients with standard ranked scales. Amer. J. Phys. Anthro. 68:263-267.

Turner CG II (1986) Dentochronological separation estimates for Pacific rim populations. Science 232:1140 1142 .

Turner CG II (in press) Late Pleistocene and Holocene population history of East Asia based on dental variation. Am. J. Phys. Anthropol.

Turner CG II, and Hanihara K (1977) Additional features of Ainu dentition. Am. J. Phys. Anthropol. 46:1324

Ushijima Y (1954) The human skeletal remains from the Mitsu site, Saga Prefecture, a site associated with the "Yayoishiki" period of prehistoric Japan. Q. J. Anthropol. 1:273-303.

Vivien de Saint-Martin (1872) L'ethnologie du Grand Archipel d'Asie. Une lacune à remplir dans la classification des races humaines. L'Année Géogr. 9:90-97.

von Baelz E (1901) Menschen-Rassen Ost-Asiens mit spe- cieller Rücksicht auf Japan. Z. Ethnol. 33:166-189, 202-207, 245-249, 393-394.

von Baelz E (1911) Die Riu-Kiu-Insulaner, die Aino und andere kaukasieränliche Reste in Ostasien. Korres. Blatt Dtsch. Ges. Anthropol. Ethnol. Urgesch. 42:187191.

Watanabe $H$ (1986) Community habitation and food gathering in prehistoric Japan: An ethnographic interpretation of the archaeological evidence. In RJ Pearson, GL Barnes, and KL Hutterer (eds.): Windows on the Japanese Past: Studies in Archaeology and Prehistory. Ann Arbor: Center for Japanese Studies, University of Michigan, pp. 229-254.

Watanabe S (1938) Kraniologie der Yakumo-Aino. In S Kodama (ed.): Crania Ainoica. Sapporo: Kaiserlischen Hokkaido Universität, pp. 1-174.

Watanabe S (1981) Ainu. In I Schwidetzky (ed.): Rassengeschichte der Menschheit. 8. Lieferung. Asien I: Japan, Indonesien, Ozeanien. Mümchen: R Oldenbourg, pp. 71-78.

Yamaguchi B (1967) A comparative osteological study of the Ainu and the Australian aborigines. Canberra: Australian Institute of Aboriginal Studies, Occasional Papers in Human Biology, Vol. 10, pp. 1-75.

Yamaguchi B (1982) A review of the osteological characteristics of the Jomon population in prehistoric Japan. J. Anthropol. Soc. Nippon [Suppl.] 90:77-90. 